\title{
دراسة حول حملة منظمة العفو الدولية لإلغاء تطبيقها عالميا وبينها في العالم الإسلامي
}

\author{
Ali Hamdan \\ Fakultas Syariah UIN Maulana Malik Ibrahim Malang \\ E-mail: alihamdan@syariah.uin-malang.ac.id
}

\begin{abstract}
Abstrak
Islam memperhatikan dan memelihara lima hak dasar dalam syari'atnya. Yaitu: memelihara agama, jiwa, akal, keturunan dan harta. Pelanggaran terhadap lima hak dasar ini akan dianggap sebagai tindak pidana dan kriminal yang layak untuk mendapatkan hukuman yang setimpal. Sebagian Organisasi Ilmiah, Sosial, yayasan asing, dan lembaga non pemerintah (NGO), salah satunya Yayasan Amnesty International melihat, bahwa Hukum-hukum syara' bertentangan dengan Hak Azazi Manusia serta menuntut membatalkan hukum pancung (Qishas). Sumber tuntutan yang mencurigakan ini hanya satu, yaitu intoleransi dan resistance terhadap islam yang disebabkan ketidak tahuan yang jelas terhadap hukum syara', justifikasi dan realitasnya.
\end{abstract}

$$
\begin{aligned}
& \text { اعتنى الإسلام بحفظ الضروريات الخمس التي اتفقت الشرائع الإلهية على حفظها، وهي: }
\end{aligned}
$$

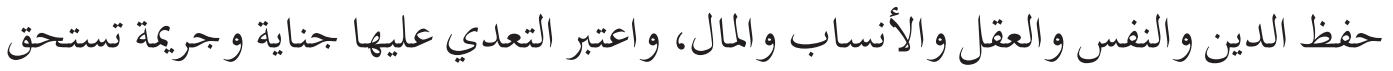

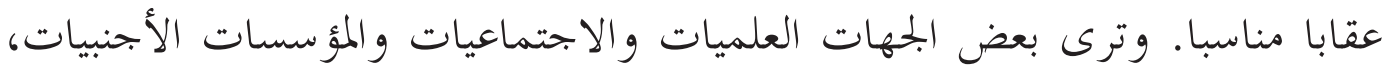

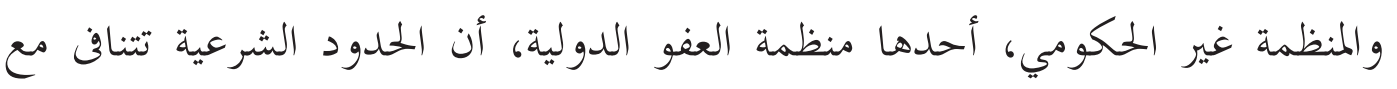

$$
\begin{aligned}
& \text { حقوق الإنسان، وتطالب بإلغاء عقوبة الإعدام. ومصدر هذه المطالبات المشبوهة شيء }
\end{aligned}
$$

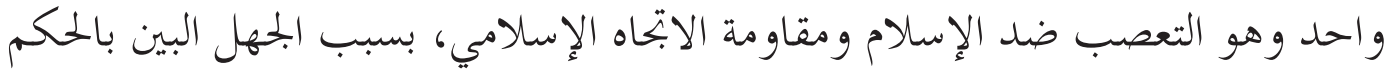

$$
\begin{aligned}
& \text { الشرعي ومسوغاته و حقيقته. } \\
& \text { كلمات السرية : الإسلام، عقوبة الإعدام، منظمة العفو الدولية }
\end{aligned}
$$

$$
\begin{aligned}
& \text { لإثتم والعقاب الأخروي فقط، ومنها ما يجتمع } \\
& \text { فيه الوصفان: العقاب في الدنيا، والعقاب في }
\end{aligned}
$$

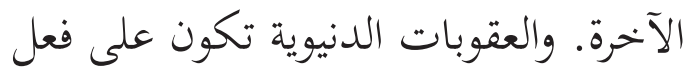

$$
\begin{aligned}
& \text { حرّم أو ترك واجب، وهي نوعان عقوبة مقدّرة، }
\end{aligned}
$$

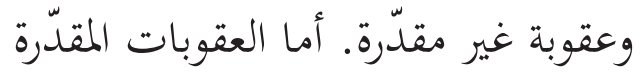

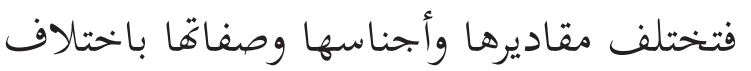


قطع عضو 72. ولا يتنفذ القصاص إلا إذا توافرت

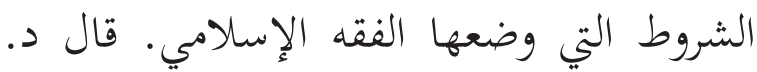
مصطفى ديب البغا: "القصاص هو معاقبة الجحاني المتعمد بمثل جنايته، ك38، وقال د. د. وهبة الزحيلي:

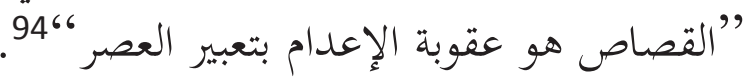
إذا، بالنظر إلى المعنيان بين الإعدام والقصاص لغويا بجد وجود الفرق بينهما أساسيا، الإعلام الفيان

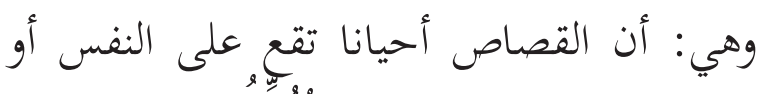

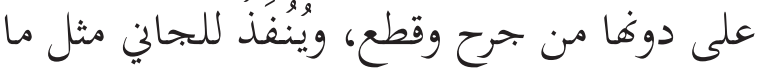

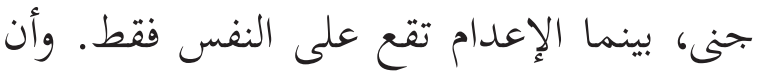
القصاص تقع للفاعل وهو الجاني، تنفيذا وتطبيقا

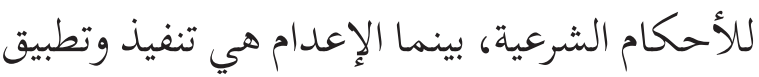

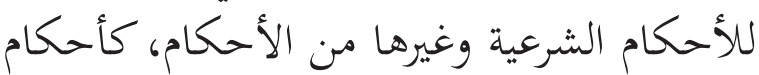
الوضعي، وأحكام الدولة أو نظام الدكتاتورية الدام كاحكام أوغيرها من النظام.

الشريعة الإسلامية بين يدي اللغة والفقه شريعة الإسلامية هي المصطلحات القديمة المعروفة لدي المسلمين منذ بدأ الإسلام المات في عهد النبي صلى الله عليه وسلم، وما زال

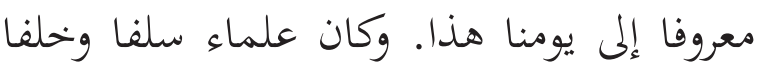

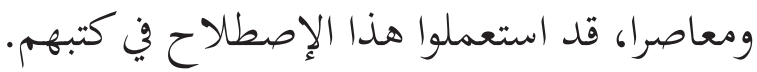
ولعلاقة هذا الإصطلاح بأحكام الفقه ومصادره

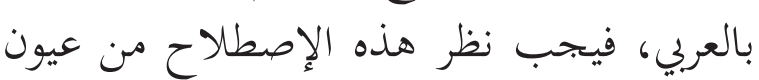

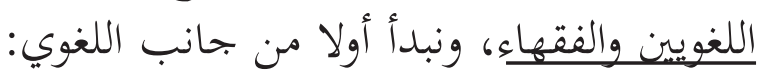

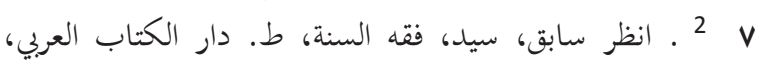

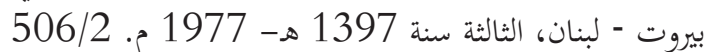

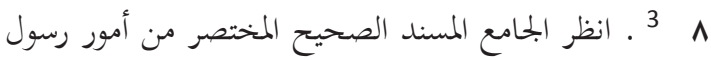

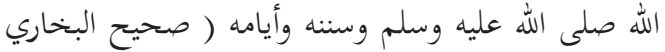

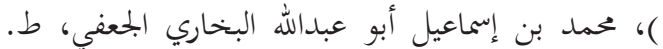

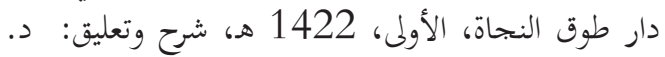
مصطفى ديب البغا، تحقيق: عممد زهير بن ناصر الناصر. 9/4

9 9 4 . انظر الزحيلي، الفقه الإسلامي وأدلنه 3142/4
أحوال الجرائم، وكبرها وصغرها وبحسب حال ألمال

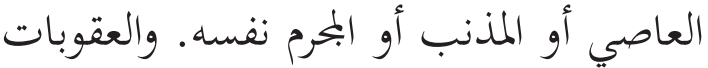

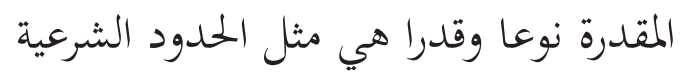
الخمسة،11، ومن بينها الإعدام أو القصاص.

مفهوم عقوبة الإعدام والقصاص بين يدي اللغة والفقه

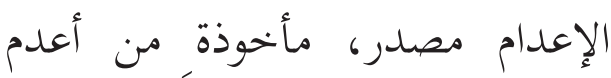

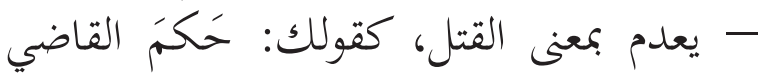

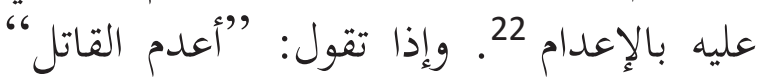

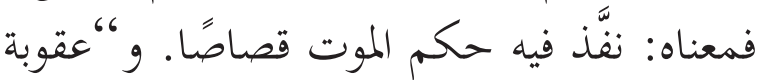

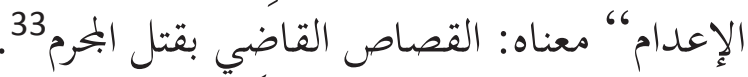

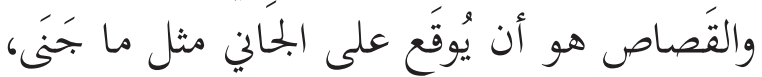
النّفس بالنّفس والجحرح بالجرح 44.

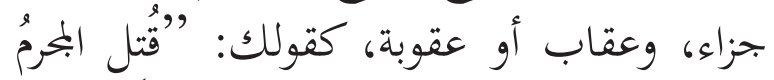

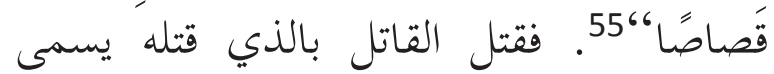

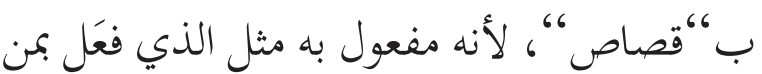

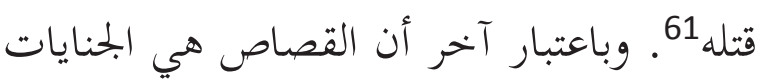

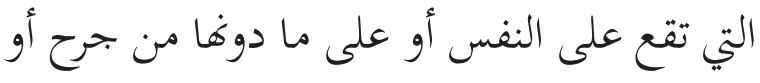
1 1. انظر الزحيلي وهبة بن مصطفى، الفقه الإسلامي وأدلته.

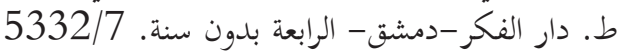

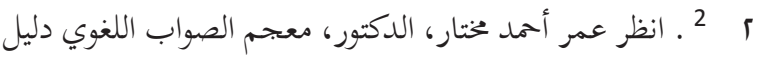

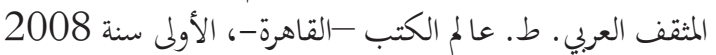
55/1. r 3. انظر عمر أممد خختار، معتم اللغة العربية المعاصرة، ط. عالم

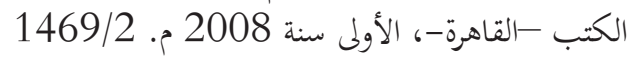

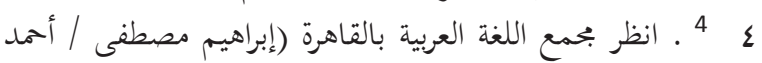

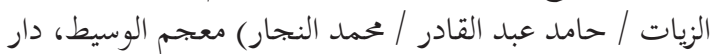

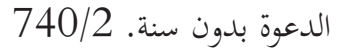
ه 5 ـ انظر آن دُوزي، رينهارت بيتر، نقله إلى العربية وعلق عليه :

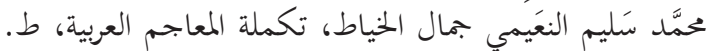
وزارة الثقافة والإعلام، الجمهورية العراقية، الأولى، من 1979

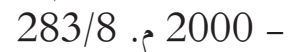
1

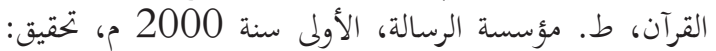

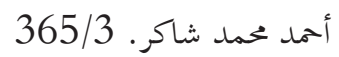


لا يخلو من ضعف أو نقص أو محاباة141. وليس

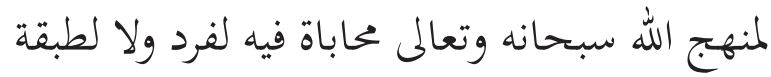

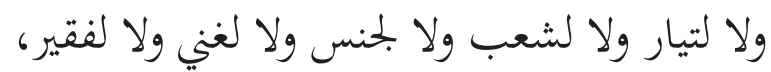

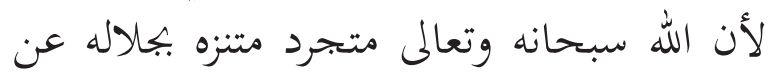

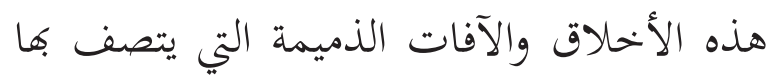

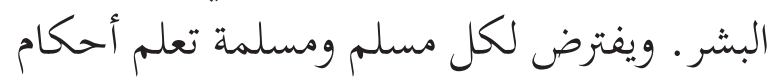
شريعته، ومعرفة الفرائض والحلال والح والحرام، والمعاصي والعقوبات أو الجزاءات المقررة في الإسلام.

\section{نشأة منظمة العفو الدولية وحملتها}

بعد عقد إجتماع دولي الأول بحضور

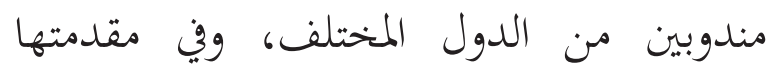

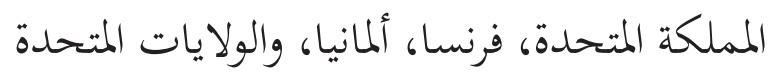

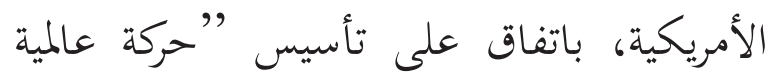

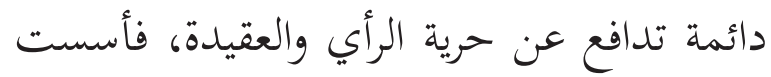

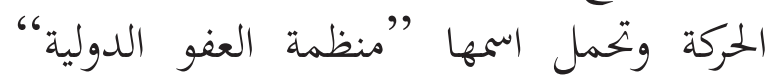

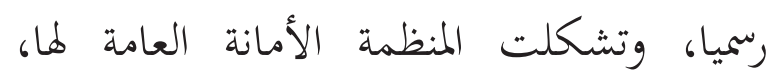
ومقرها في لندن. 152وهذا الإجتماع أثر حملة المانة المانة لمان

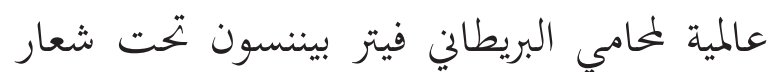

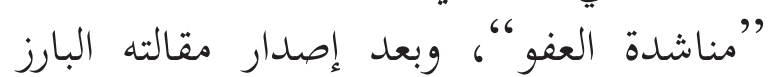

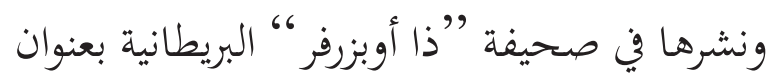

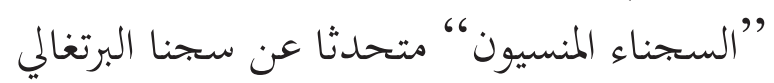

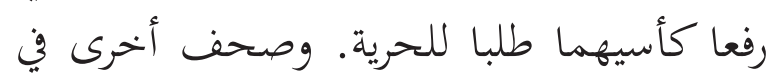

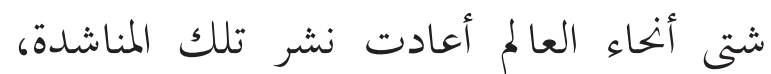

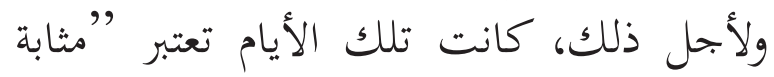
اللبنة الأولى لإنشاء منظمة العفو الدولية،". وفي

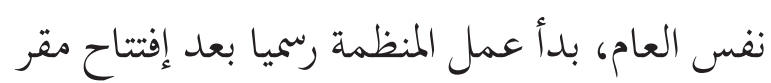

$$
\begin{aligned}
& \text { 1/ 1 . انظر المهاي، حسين بن محمد، الشورى في الشريعة } \\
& \text { الإسلامية، بدون الناشر، سنة } 2006 \text { م. ص: } \\
& 10
\end{aligned}
$$

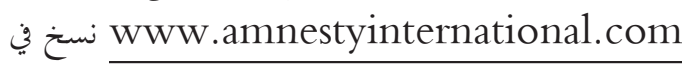

$$
\begin{aligned}
& \text { ديسمبير عام } 2011 \text { م. }
\end{aligned}
$$

إن الشريعة الإسلامية هي الكلمتان المركبتان من

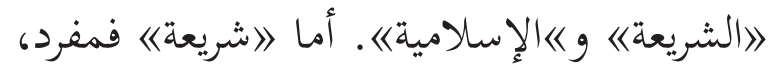

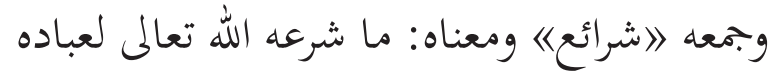

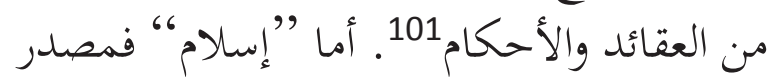

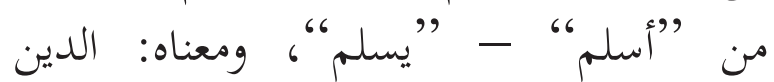
السماوي الذي بعث الله به محمدا صلى الله عليه وسلم. إذا، فالشريعة الإسلامية هي: تعاليم القرآن

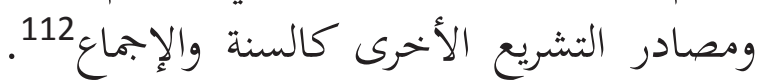
وأما الشريعة الإسلامية من نظرة الفقهاء فعليهم

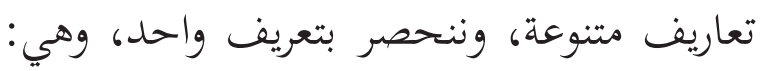

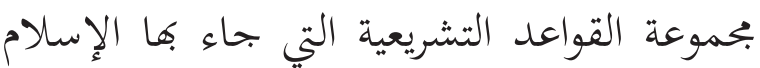

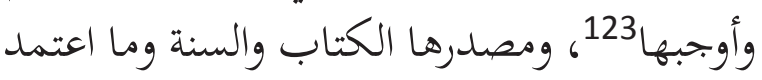
عليهما من اجتهادات فقهاء الإسلامب134، وأنها وأها

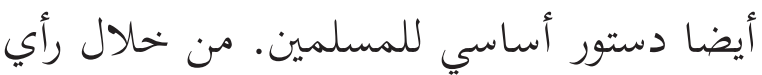

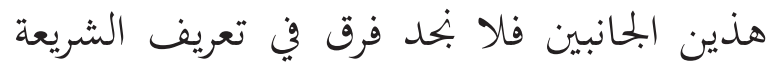

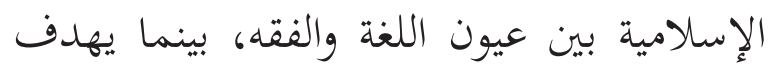

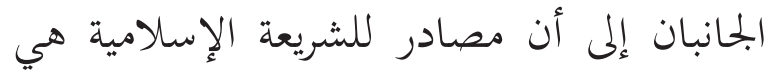

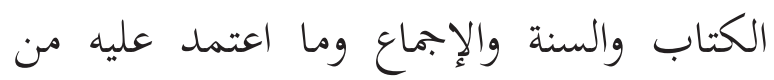
إجتهادات الفقهاء.

وأما مكان الشريعة الإسلامية في منهج

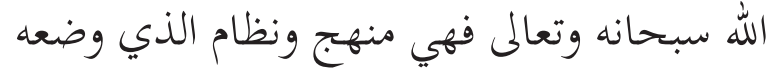
للإنسانية، وابتعث به رسوله محمد صلى فئل الله عليه

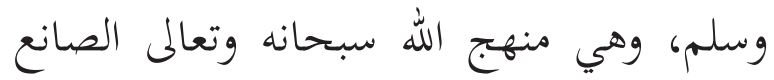

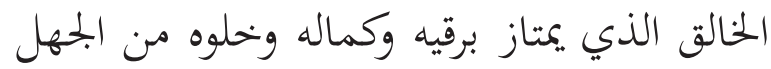

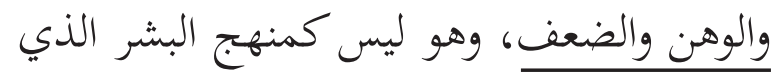

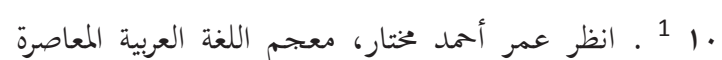
1189/2

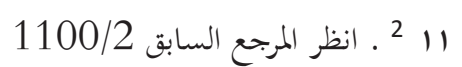

II 3 ـ ـ انظر عودة، عبد القادر، التشريع الجنائي الإسلامي مقارنا

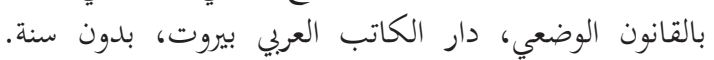
251/1 r/ 4 ـ . انظر عفانة، حسام الدين بن موسى، فتاوى يسألونك، ط.

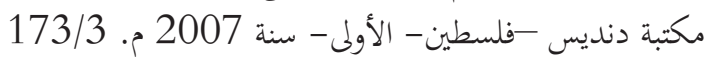


حقوق الإنسان، والثاني منحت إلى منظمة العفو

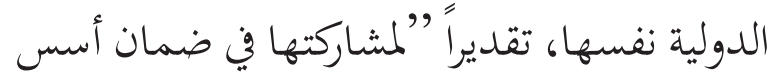

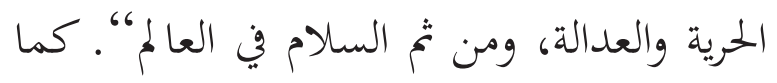

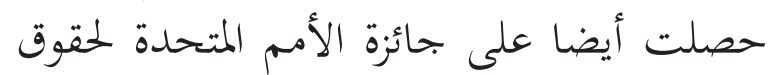

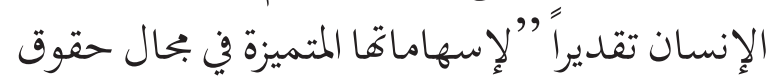
الإنسان،". وتطورات التحركات للمنظمة أهدافا

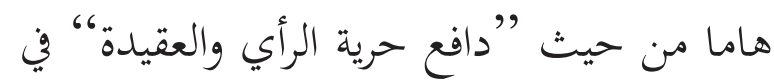

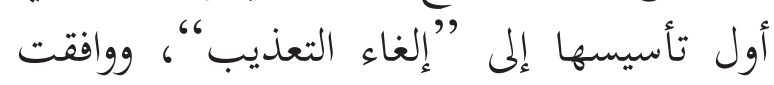
الأمم المتحدة على تلك الألى الأهداف باعتمادها بالإجماع "إعلان مناهضة التعذيبها 1975 م. وأصبح لدى المنظمة ما يربو على على 70 ألف عضو في 65 بلداً.

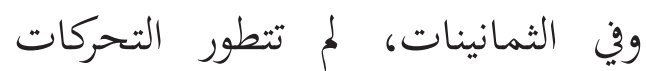
للمنظمة بنشاطات متنوعة بأشكال متزايد سوى إلم الثركات إصدار التقرير ومملة عالمية بعرض موسيقي. وأما التقرير فهي مثل أصدار تقرير خاص عن عملئ عمليات

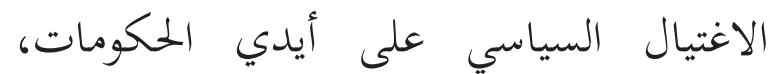

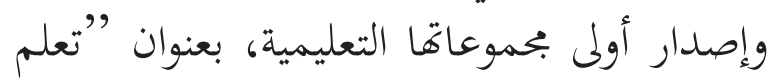

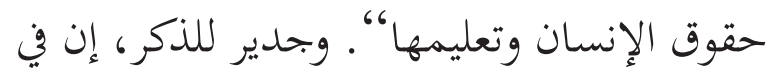

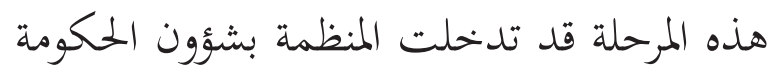

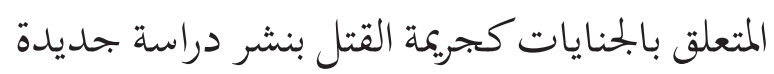

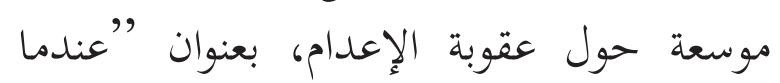

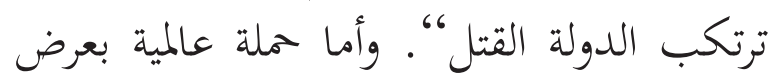
موسيقي فمثل حملة فرع المنظمة في الولايات

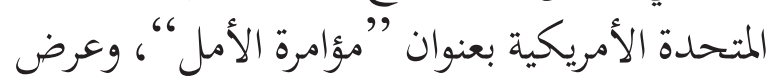

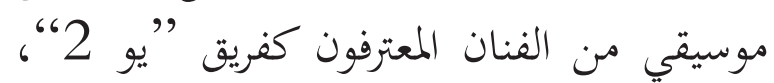

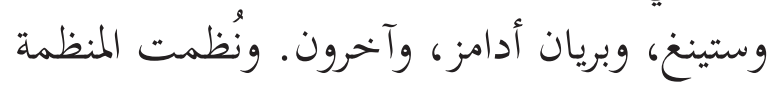

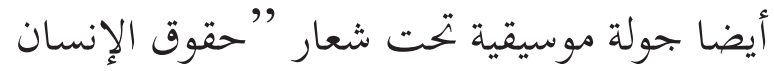
الآن"، بمشاركة الفنانون المعترفون كستينغ، وآخرون، حيث سافروا إلى 19 مدينة في 15 دولة، بمشاهدة عدة ملايين عيون. وذلك بمناسبة
صغير للحركة، وذلك في مكتب بيننسون في مبنى "ميتر كورت" في لندن. ومههم أن ننبه، أن إعلان فينان لمنظمة العفو الدولية هي في اليوم العالمي لحقوق

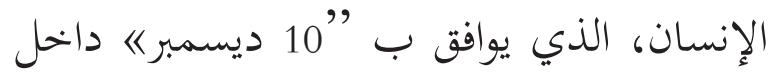
كنيسة 》سان مارتن إن ذا فيلدز بـ في لندن. منذ احتملت الحركة باسم "المنظمة العفو

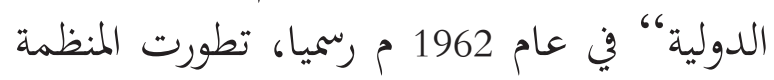
بشكل متزايد، رغما على أهمية أهدافها وشعارها

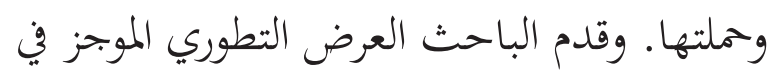
كثير من الإقرارات سلمتها المنظمة، والتحركات المرات التي قامت بها على مر السنين منذ تأسيسها حتى الإنى الآن. 161أما الإقرارات التي سلمتها المنظمة، فقد فئد

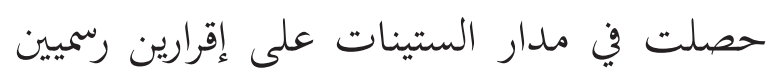

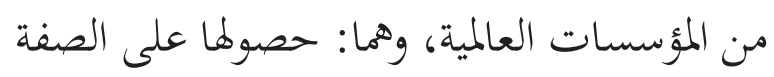

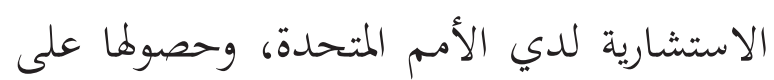

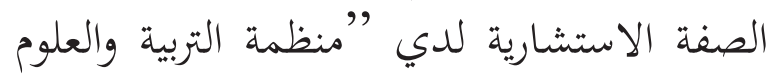
والثقافة، (اليونسكو)، المؤسسة التابعة للأمَّمٍ

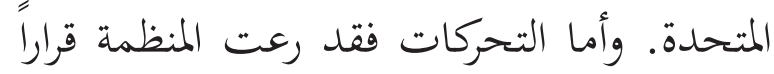

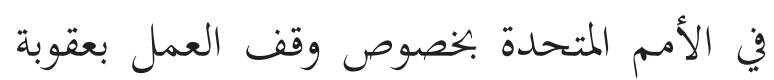

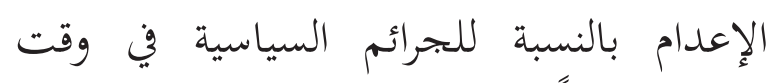
السلم، تمهيداً لإلغاء العقوبة في غاية المطاف. ثمافية

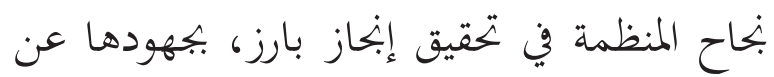
إطلاق سراح ألفين من سجناء الرأي، وأعضاءها في ثمانية عشر دولة.

وفي مدار السبعينات فقد حصلت المنظمة

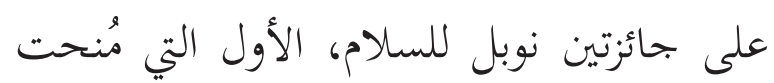

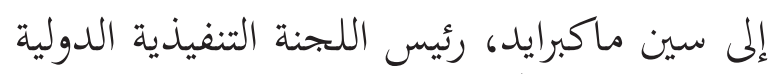
للمنظمة، تقديراً لجهوده طوال حياته في سبيل 11 1 1 . انظر تاريخ التطور للمنظمة في موقعه على الإنتيرنيت

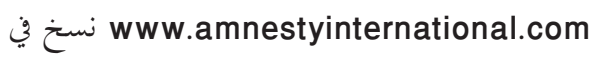
ديسمبير عام 2011 م. - - lom 
بعنوان "قسوة ولا إنسانية وإهانة لنا جميعاً"،

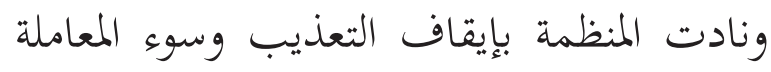

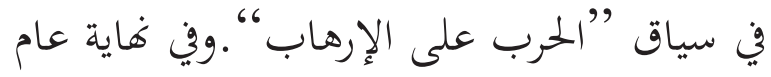
2007 م، أعلنت المنظمة بأهما يربو على 2.2 مليون من الأعضاء والمؤيدين والمشتركين في أكثر

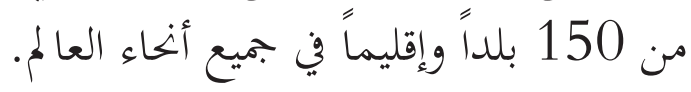
وفي بداية تأسيس المنظمة العفو الدولية لم

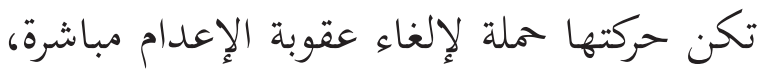

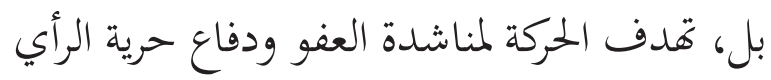

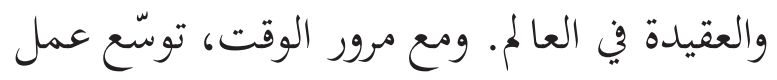

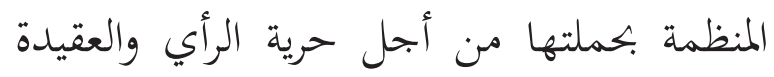

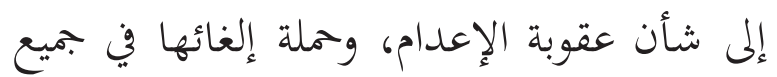

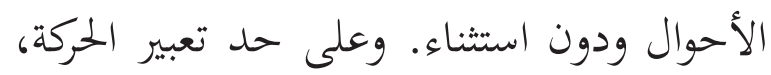

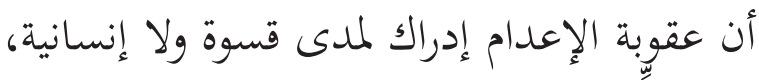

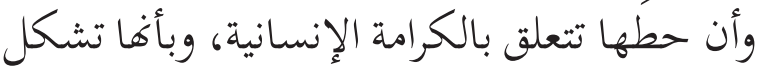

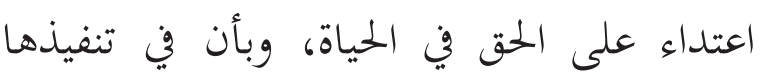

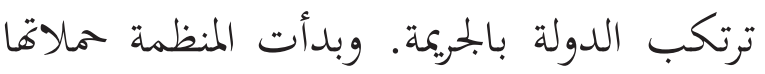

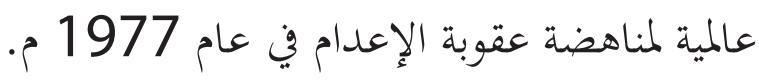
وبعد مرور ثلاثين سنة، فإن 139 13دولة قد ألغام ألغت هذه العقوبة، في القانون أو في الواقع الفعلي. وما زالت تطبق العقوبة سوى 58 دولة، بينما تستخدمها، في الواقع الفعلي عدد من الدول.

وأما استخدام الأساليب في تنفيذ عقوبة الإعدام في العالم حسب تعبير المنظمة عفو الدولية فمتنوعة، نظرا إلى خلفية التاريخية

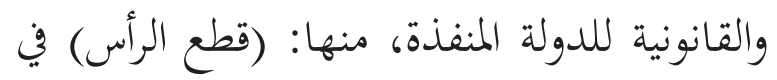

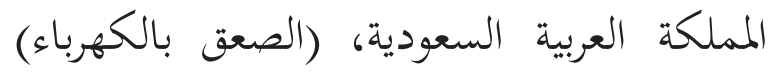

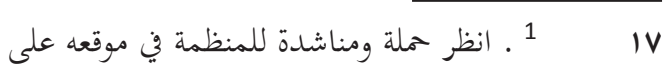
الإنتيرنيت WWw.amnestyinternational.com
اليوم العالمي لحقوق الإنسان. ولا يتأكد حضور

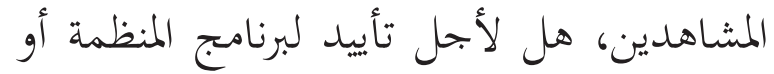

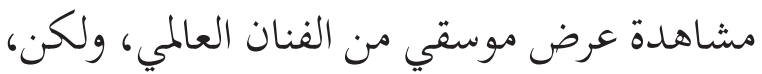

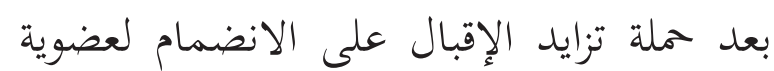
المنظمة في كثير من البلدان في أعقاب الجولة. وفي التسعينات، حصلت المنظمة ثلاثون

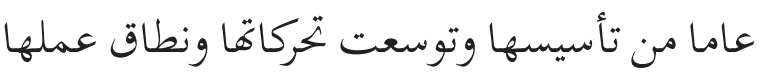

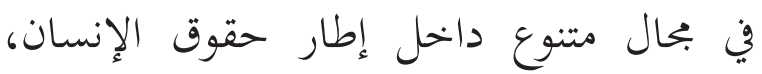
منها: الانتهاكات على أيدي جماعات إطات المعار الإنة

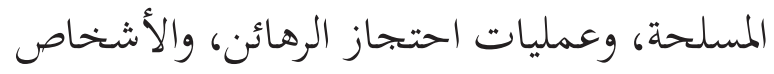

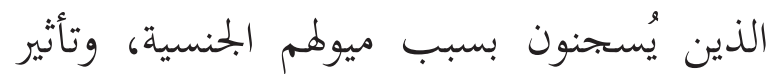

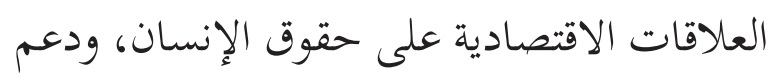

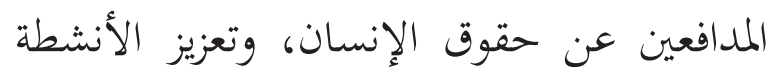

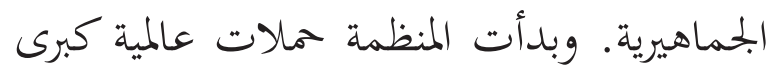

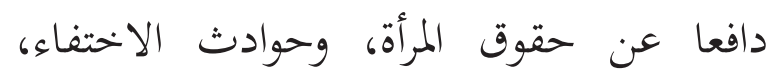

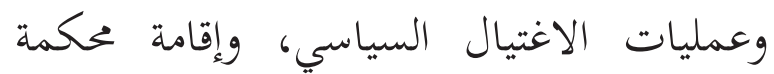
جنائية دولية، وهو الاقتراح الذي تبنتيات الأبيال الأمم المتحدة في عام 1998. ومع بلوغ المنظمة عامها لإنها

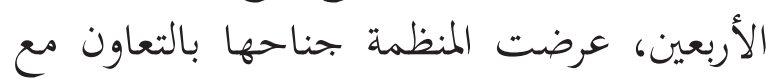

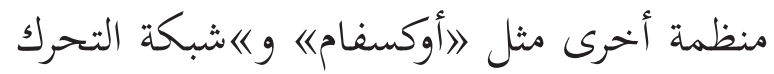

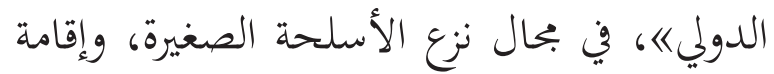

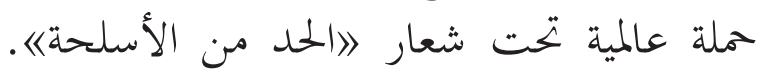
وتوسعت التحركات المنظمة في محال حماية المرأة

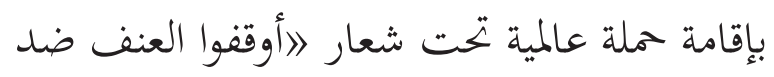
المرأة《ا.

وبعد أحداث إحدى عشر سبتمبير

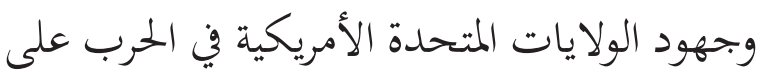

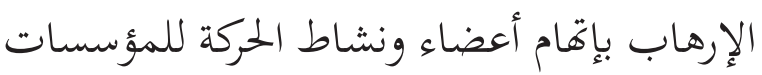

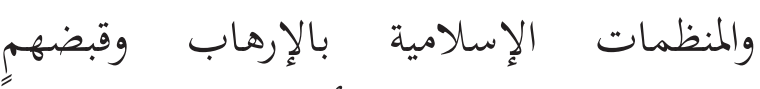
وسجوفهم بدون المحاكمة، أصدرت المنظمة تقريراً

$$
\text { نسخ في ديسمبير عام } 2011 \text { م. }
$$


العظمى جزاؤها الاعدام203. وقد تعارض منظمة العفو الدولية عقوبة الإعدام في جميع الأحوال الاعدال بدون أي استثناء، وبصرف النظر عن طبيعة الجريمة

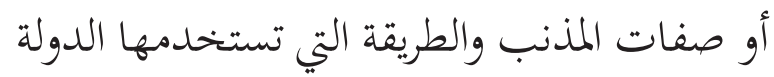

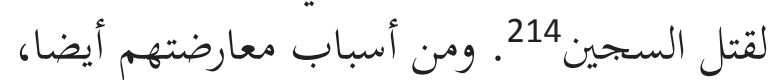
ترون أن الحدود الشرعية تتنافى حقوق الإنسان

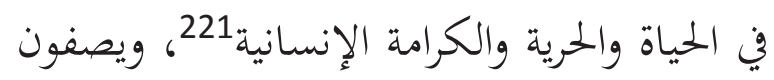

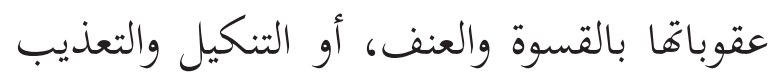

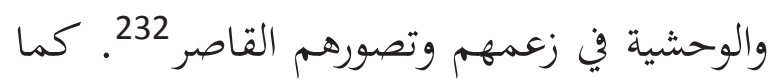
تعرضت أيضا الكتاب وبينها كتاب المستمدين المتاصرين للهجوم والسخرية والاستهزاء، بأن العقوبات البات المبنات

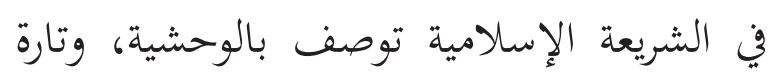

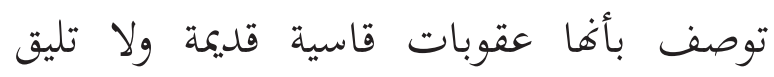

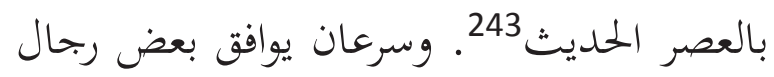

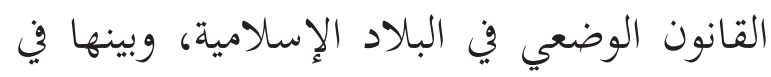

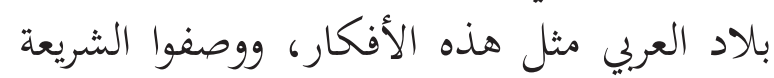

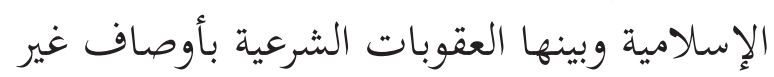

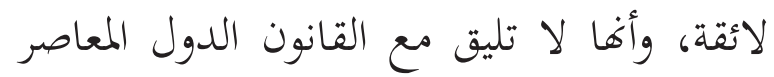

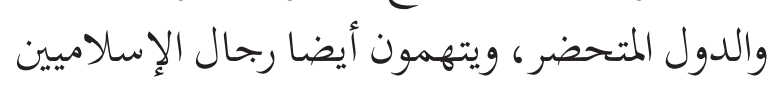
وكل من يطالب بتطبيق الشريعة الإسلامية بأفم الإنم متشددون متعصبون، ولكن لاكن لا يقظون أو لا يبالون

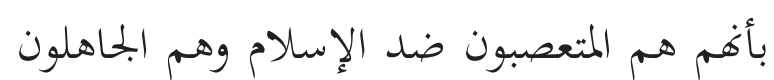

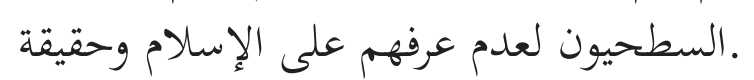

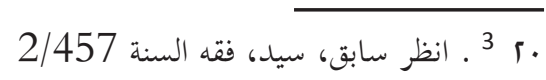

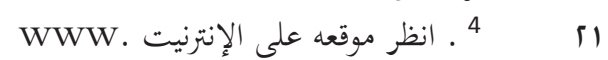

amnestyinternational.com آ 17 . انظر الزحيلي، وهبة، الفقه الإسلامي وأدلته

5324/7

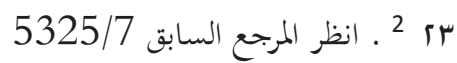

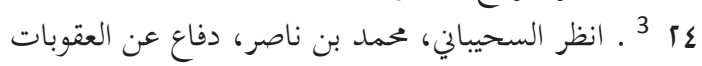
الإسلامية، ط. الجامعة الإسلامية بالمدينة المنورةالسادسة عشر - العددان الثالث والستون، الرابع والستون رجب - ذو الحجة سنة 1404 هـ ص: 77
في الولايات المتحدة الأمريكية، (الشنق) في بنغلاديش وبابوا غينيا الجحديدة، (الحقنة المميتة)

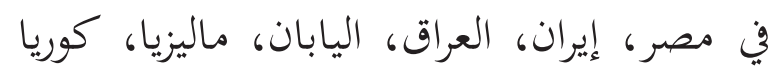
الشمالية، سنغافورة، السودان، سوريا. (الإعدام إئان رمياً بالرصاص عن قرب في مؤخرة الرأس) في الإعداف

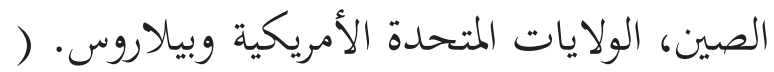

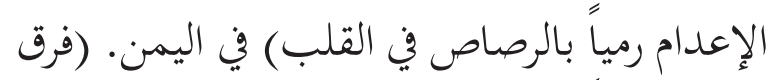

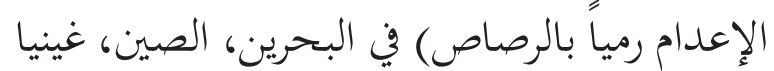

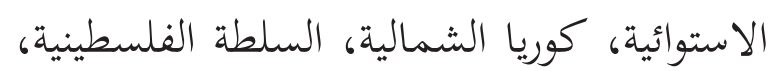

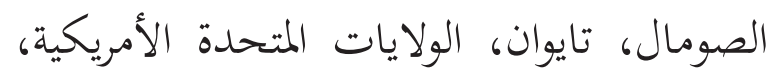
فيتنام وإندونيسيان المان،

وفي هذه المناسبة، كان الباحث لا لا يتحدث

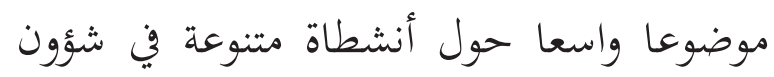
حقوق الإنسان للمنظمة، بل أحد من من حملتها وهي عقوبة الإعدام باتصالها مباشرة بالشريعة آلان من لمانية الإسلامية.

عقوبة الإعدام حسب تعبيرها ورأيها في الشريعة الإسلامية وأما عقوبة الإعدام حسب تعبير منظمة الإسما

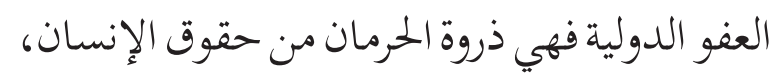

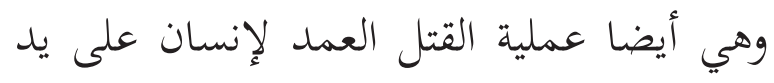

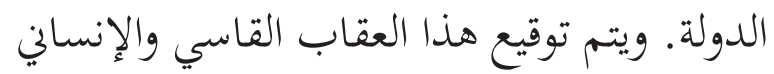

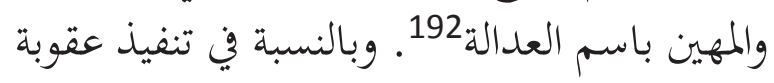

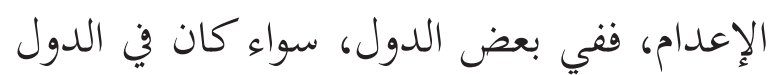

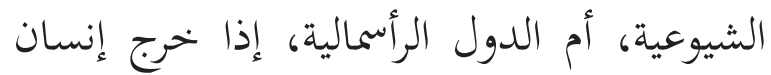

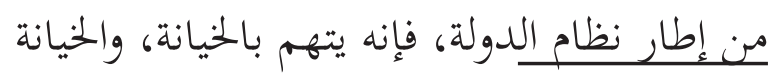

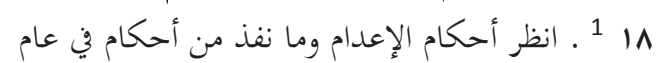

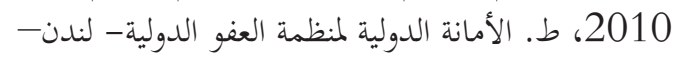

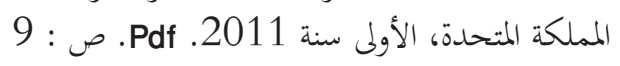
WWW. 19 amnestyinternational.com 2011 


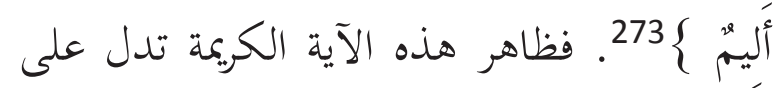

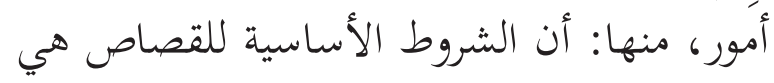

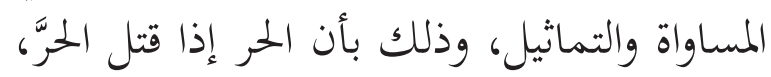

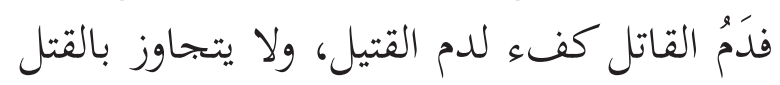

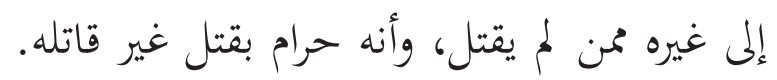

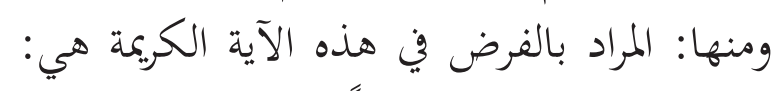

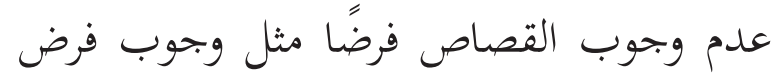

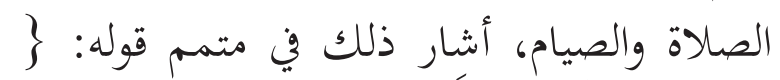

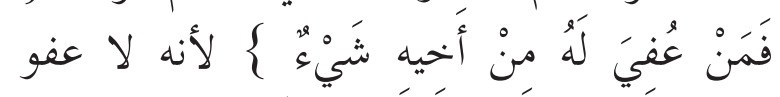

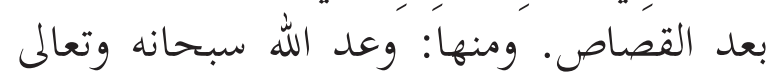

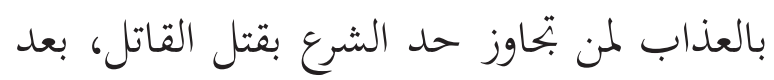
العفو أو الدية أو قتل غيره من أفراد أهله وأقربائه أو أمر منه. ومنها: لم تفرق الشريعة الإسلامية بين نفس ونفس، فالقصاص حق، سواء كان المقتول

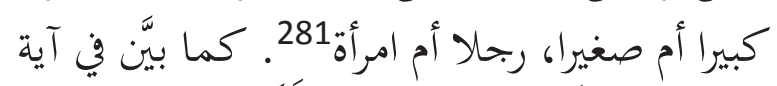

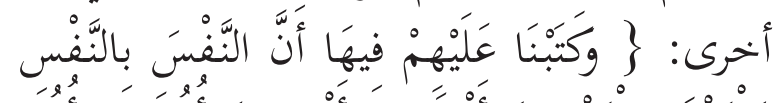

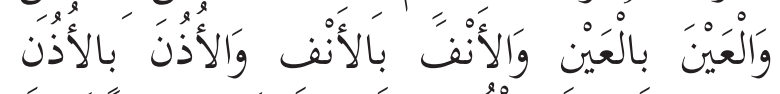

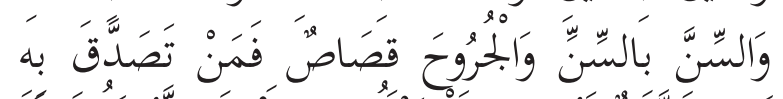

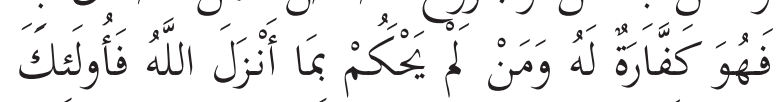
هُمُ الظَّالمُونَ $292 ،$

وأما في سنة رسول الله صلى الله عليه

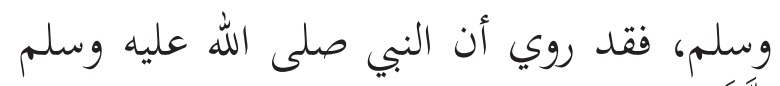

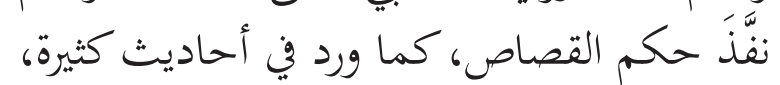

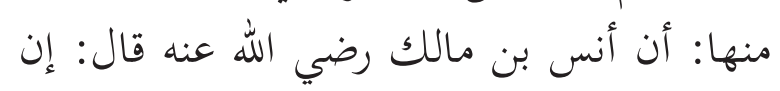

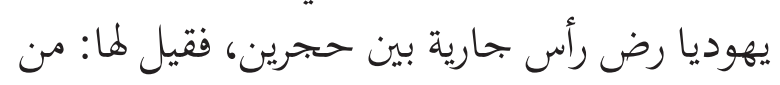

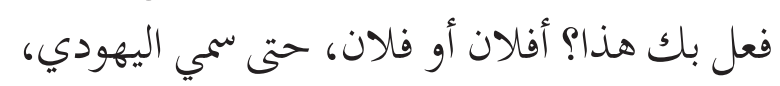

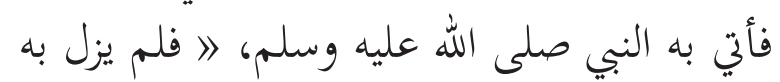

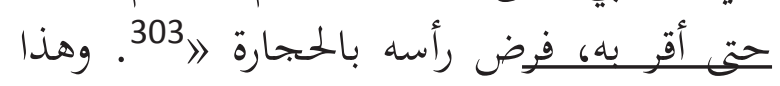

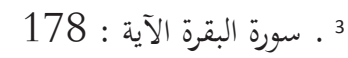

1 I 1 1 ـ انظر المرجع السابق 512/2 19 2 ـ ـ سورة المائدة الآية: 45

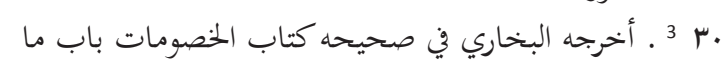

\section{موقف المسلمين تجاه هذه المعارضة}

بعد النظر إلى الشريعة الإسلامية، وحملة حركة منظمة العفو الدولية لإلغاء عقوبة الإعدام

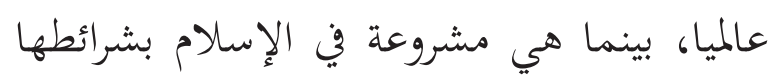
المعينة، وهي إحدى من وني أحكام الله سبحانه

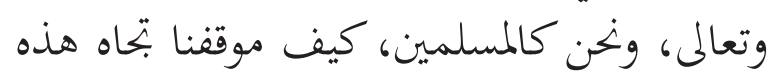
المعارضة الأجنبية، وتحاه حملتها عالمسلين كالميا في إلغاء

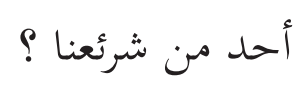

ثبوت القصاص أو عقوبة الإعدام في الشريعة الإسلامية

القصاص هو عقوبة الإعدام بتعبير

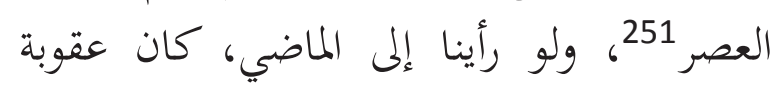

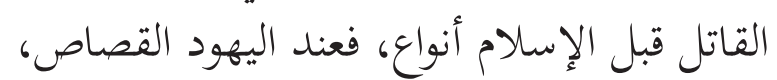

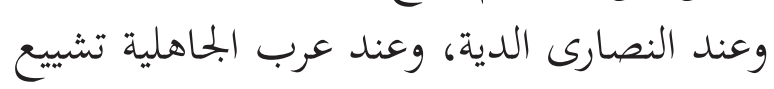

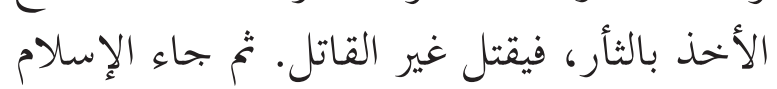

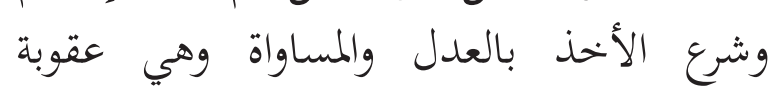

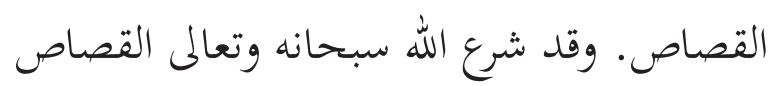
وإعدام القاتل انتقاما منه، وزجرا لغيره، وتطهيرا

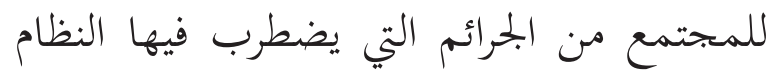

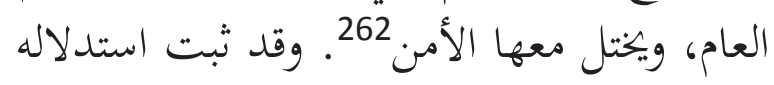

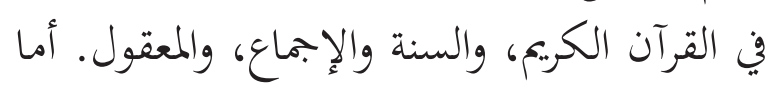

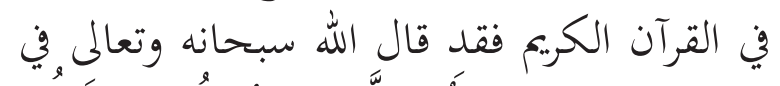

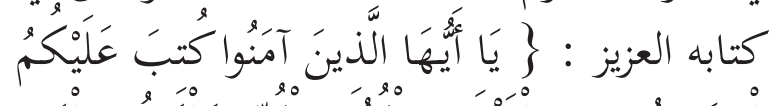

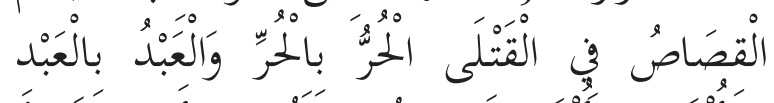

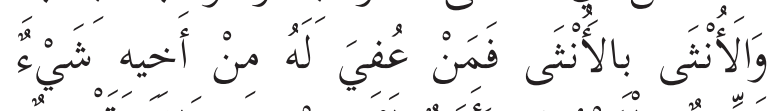

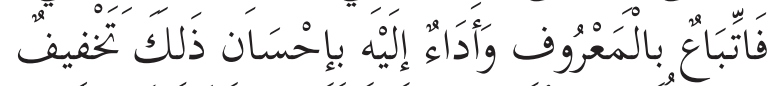

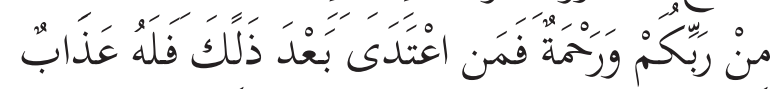

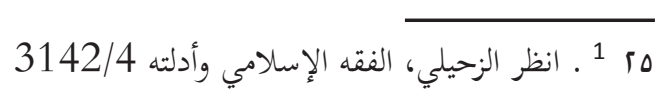

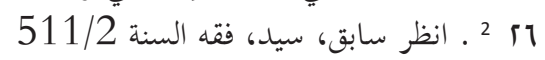




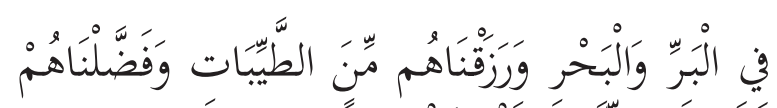

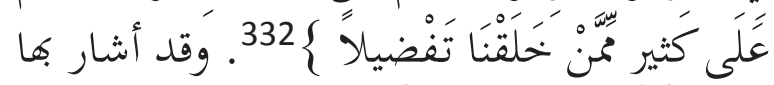

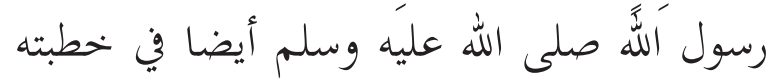

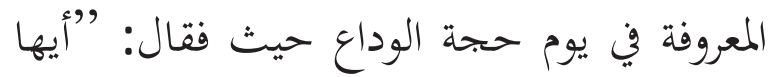

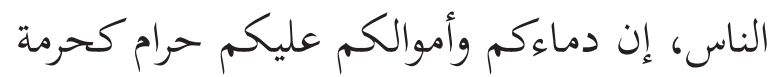
يومكم هذا، في شهركم هذا، في بلدكم هذا. ألا

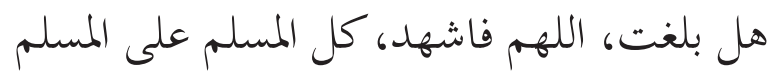

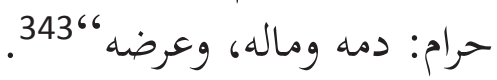

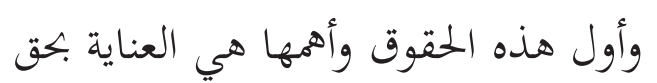

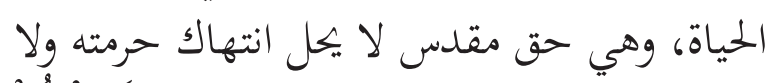

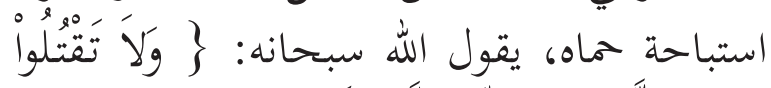

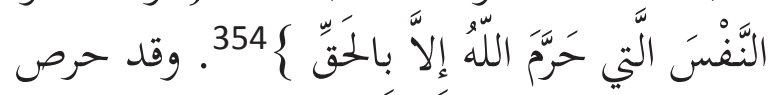

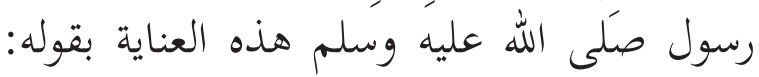

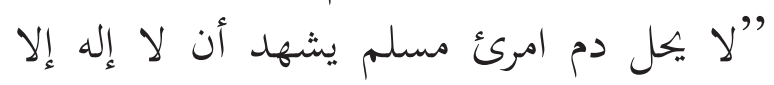

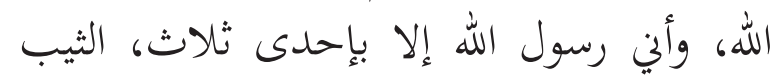

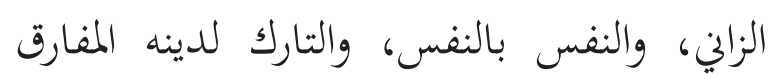

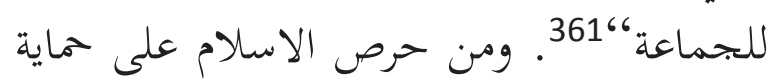

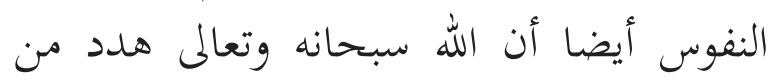

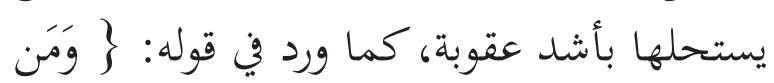

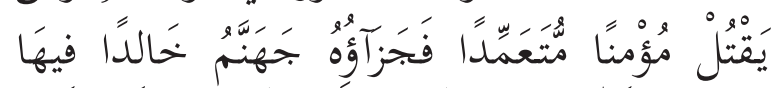

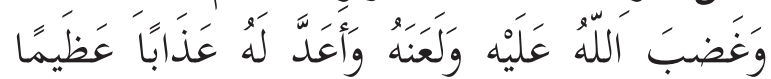

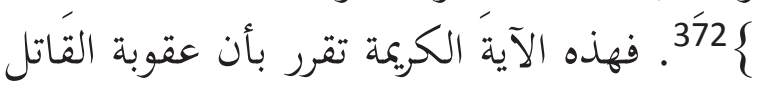
في الآخرة العذاب الأليم، والخلود المقيم والكفل: النصيب في جهنم، والغضب واللعنة والعذاب

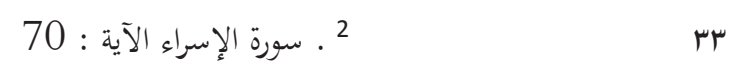
ع 3 ـ . أخرجه مسلم في صحيحه كتاب الحج باب حجة النبي

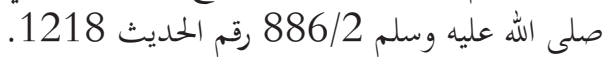

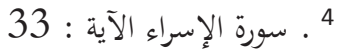

ro

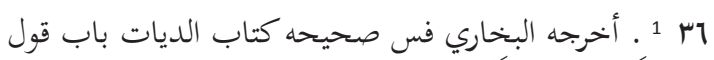

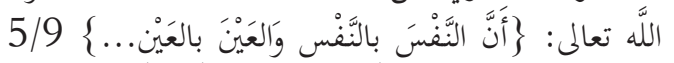

رقمَ الحديَثِ 6878

2 93

rv

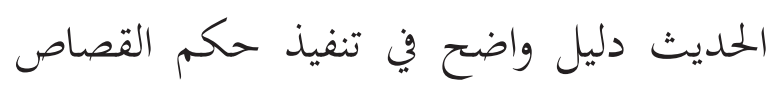

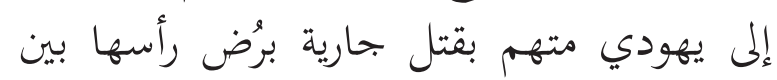

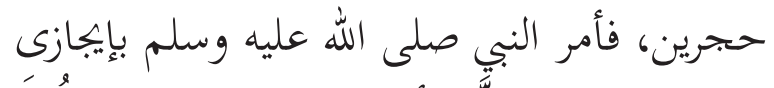

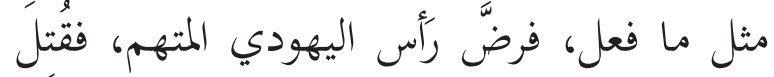

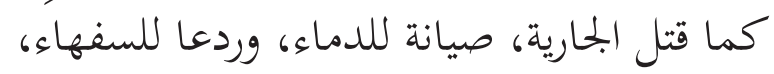

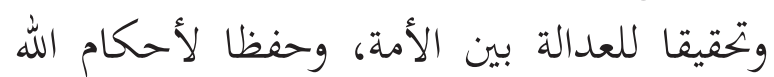

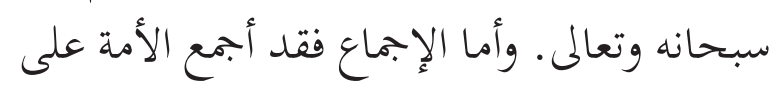

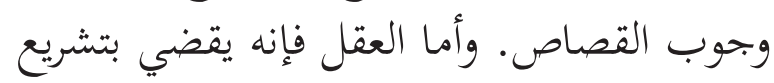

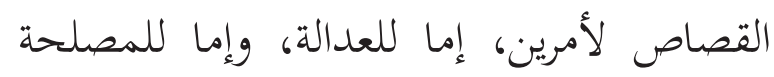

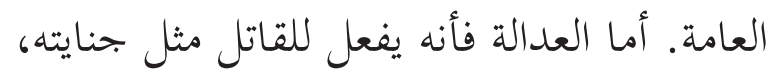

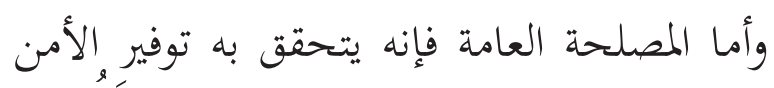

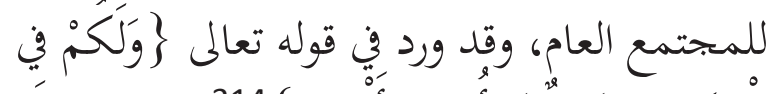

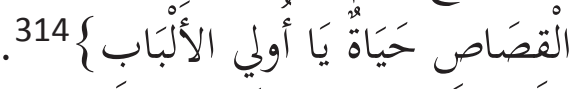

\section{كفالة الشريعة الإسلامية على حماية النفوس}

ولقد كرّم الله سبحانه وتعالى الانسان،

خلقه بيده في أحسن تقويم، ونفخ فيه من روحه، التهان

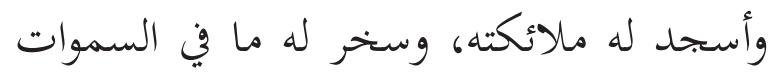

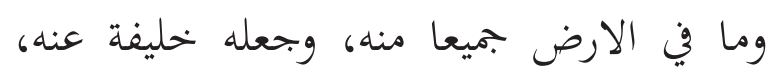

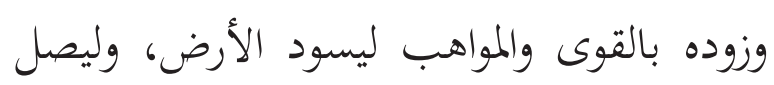

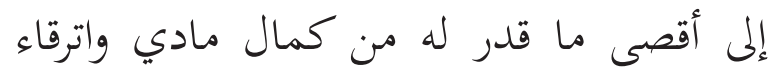
روحي 321. وهذه الكرامة تتوفر بتمليك الإنسان الكان

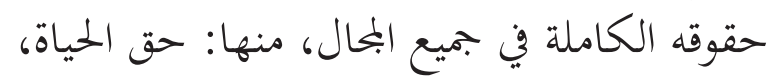

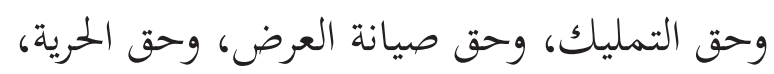

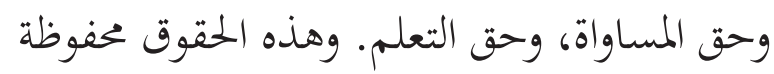

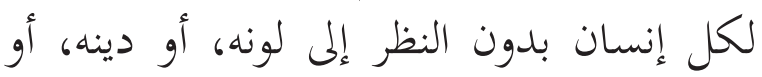

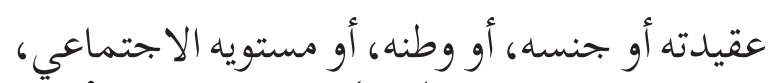

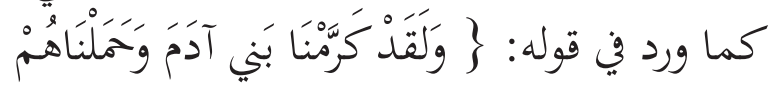

يذكر في الأشخاص والخصومة بين المسلم واليهود 4/9 رقم 6876

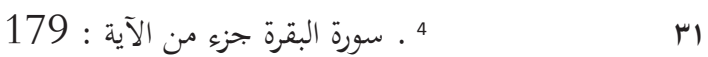
זب 1 1 . انظر سابق، سيد، فقه السنة 507/2 
فكثير، منها: يساعد على توفير الحياة الهانئة

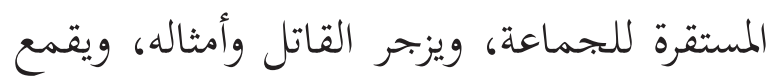

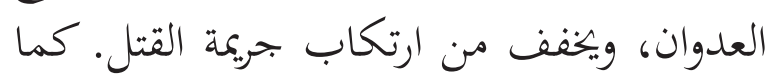

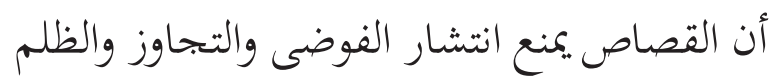

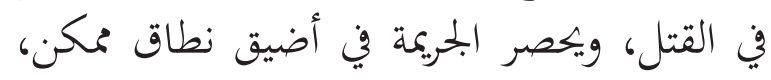
ويشفي غليل ولي القتيل، ويطفئ نار غيظه، ولفئه

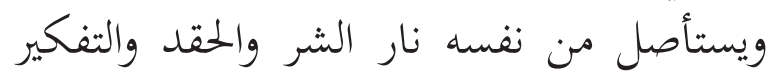

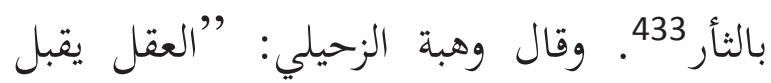
حكم القصاص لأسباب، منها: العدالة، وتحقيق

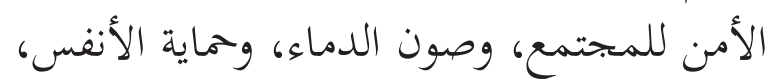

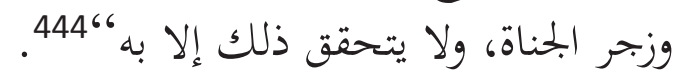

\section{تنفيذ عقوبة الإعدام في الدول الإسلامية}

كانت المصطلاحات الحديثة حول

دول المسلم والدول الإسلامية المتداولة في العالم حاليا إصطلاحين، وهما: الدول المسلم والدول الإسلامية. ونموذج من الدول المسلم كإندونيسيا وماليزيا وجمهورية مصر العربية. أما إندونيسيا

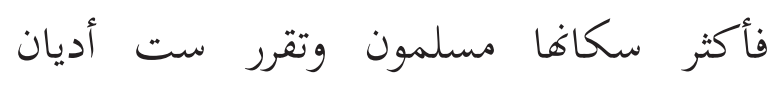
المعترف لدي الدولة، وليست الشريعة الإسلامية أساسا ودستورا للدولة. ولكن في بعض قضايا الجريمة الخطيرة، حكومة إندونيسيا تُنفذ عقوبة لئن الإعدم، كجريمة الإرهاب والمخدرات وليس في إني

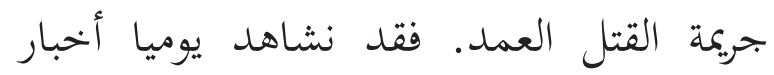
الجريمة في التلفزيون المحلي، كازدياد قضايا القتل العمد، وعملية الغصب بالقتل، أو السارق

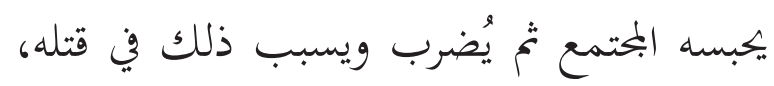

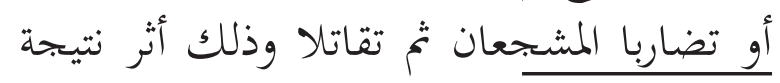

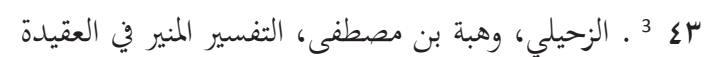

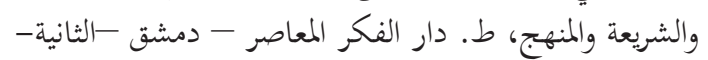
سنة 1418 هـ 107/2

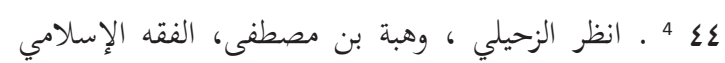

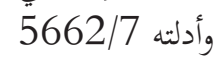

العظيم 383. وذلك لأن القتل هدم لبناء أرادة الله سبحانه وتعالى، وسلب لحياة البمني عليه، واعتداء

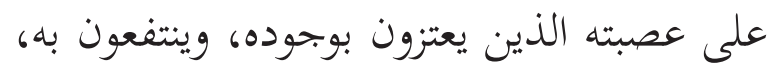
ويكرمون بفقده العون 394.

وعقوبة الإعدام هي أعلى العقوبات في

الشريعة الإسلامية، تطبقها في جريمة خطيرة مثل الإعل اعلى المعوبات القتل العمد. ولا يبجب القصاص للقاتل إلا إذا

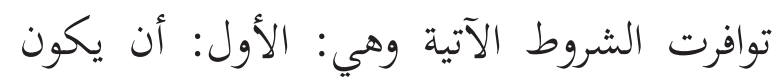

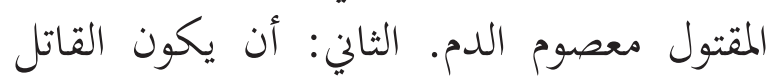

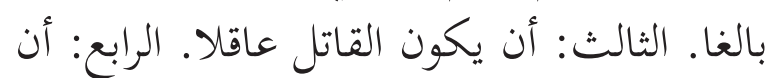
يكون القاتل مختارا. الخامس: ألا يكون التان القاتل القاتل

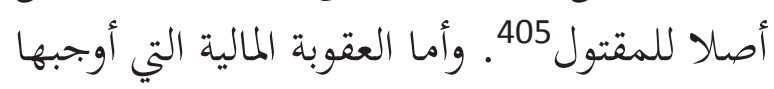

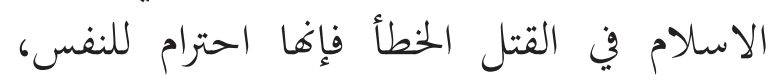
حتى لا يتسرب إلى ذهن أحد هواها، وليحتاط

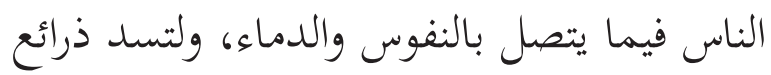
الفساد، حتى لا يقتل أحد أحدا ويزعم أن القتل كان خطأ411.

\section{حكمة مشروعية القصاص}

لقد شرعت العقوبة في الدنيا لتمنع الناس من

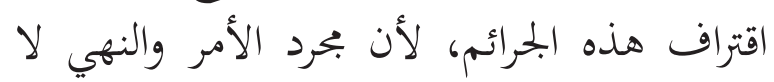
يكفي عند بعض الناس على الوقوف عند حدود

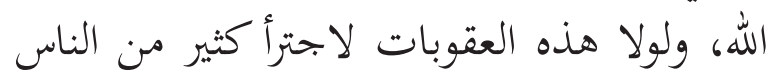

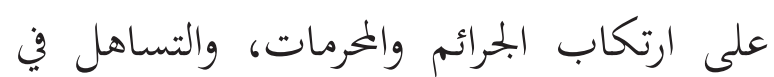
المأمورات422. وأما حكمة الجراتم مشروعية القصاص

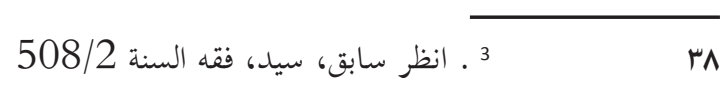

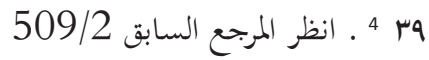

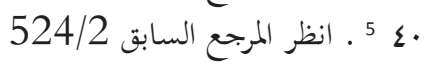

1 . انظر المرجع السابق 512/2

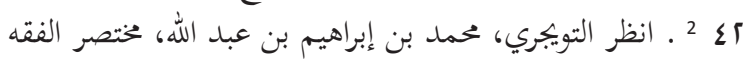

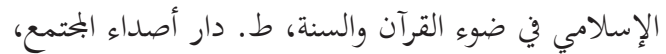

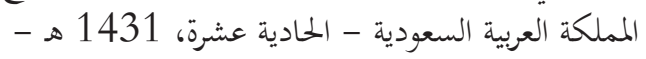
2010 م. ص: 923 
أن عقوبة الإعدام في تعبير منظمة العفو الدولية فهي ذروة الحرمان من حقوق الإنسان،

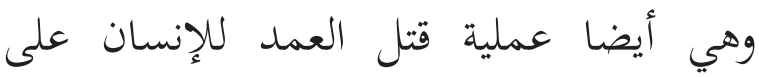

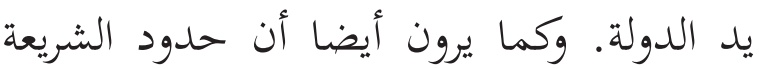
الإسلامية تتنافي حقوق الإنسان في الحياة والحيوية والكرامة الإنسانية. وغير ذلك يصفون أيضا أن عقوبة الإعدام بالقسوة والعنف أو التنية التكيل والتعذيب والوحشية. خحلافا لتعبير المنظمة، فإنان القصاص هي عقوبة الإعدام بتعبير عصري، تقع والعافية على النفس أو على دوها من جرح وقلى وقطع تنفيذا

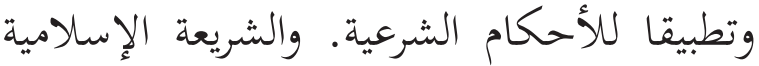
بتنفيذها لا يخالف مع حقوق الإنسان أسران أساسا

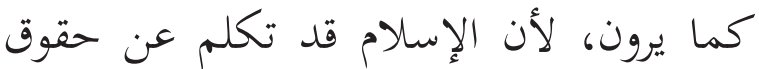

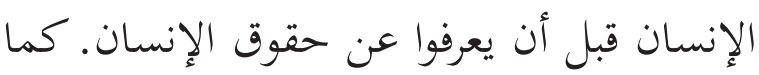

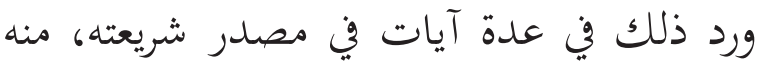

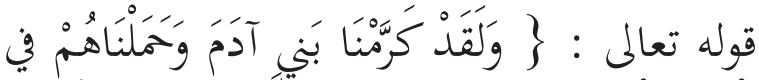

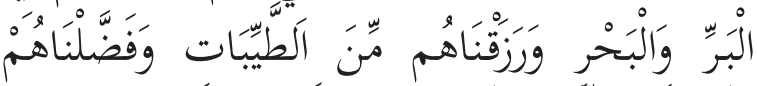

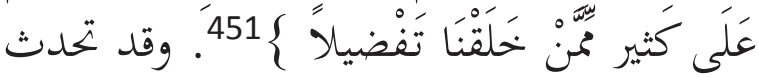

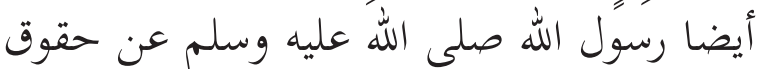

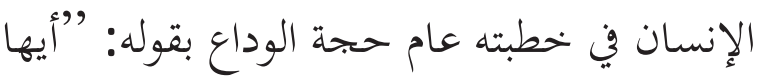

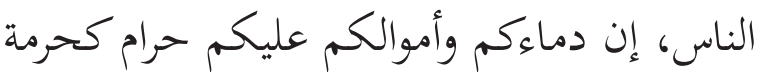
يومكم هذا، في شهركم هذا، في بلدكم هذا. ألا

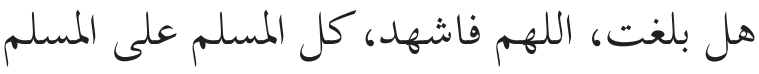

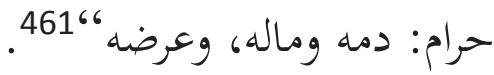

لأجل ذلك، فأن الإسلام قد تكفل

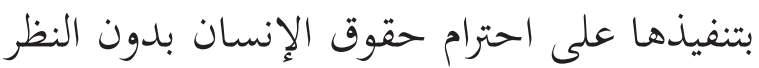

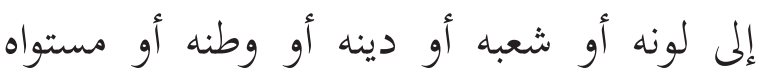

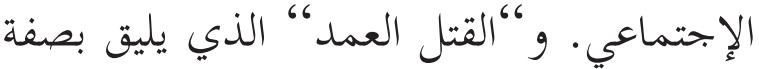

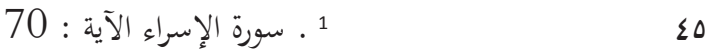

$$
\begin{aligned}
& 1 \text { 1 } 1 \text { ـ أخرجه مسلم في صحيحه كتاب الحج باب حجة النبي } \\
& \text { صلى الله عليه وسلم 886/2 رقم الحديث الحسب باب حجن البي } 1218 .
\end{aligned}
$$

سلبية لإحدى المشجعين في إنتخابات رئيس الولاية، أقليمية كانت أو محلية. إذا، لا ضمانيان

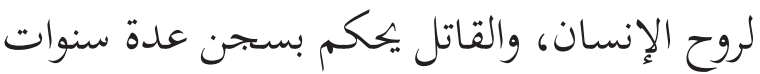

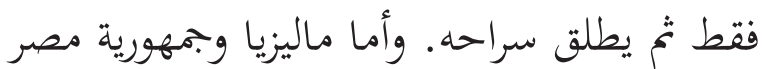
العربية فهما الدولتان تقرران الدين الرسمية لدي الدولتين هي الإسلام. وبالنسبة في تطبيق عقوبة الإعدام فكانت ماليزيا تنفذ عقوبة الإعدام لجريمة

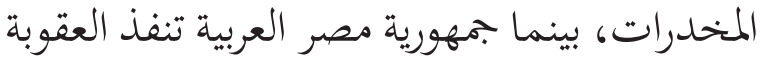
لجريمة القتل، والإرهاب والمخدرات. وأما الدول المسلم الآخر فبعضهم دولة جمهورية إشتراكية كالعراق وسوريا والجزائر، وبعضهم دولة جمهرورية

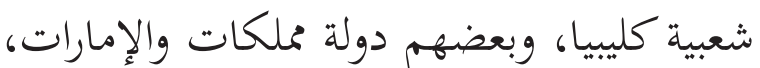
كالأردن والمغرب، والإمارت العربية المتحدة، ودولة قطر. بعض الدولة نفّذنَ عقوبة الإعدام في الماتِ جريمة خطيرة مثل قتل العمد وجريمة المخدرات.

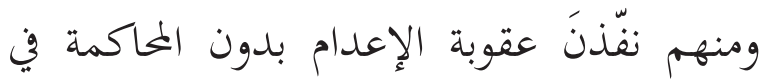

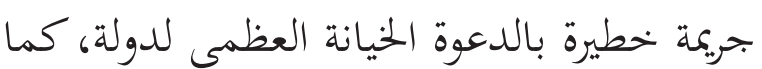
ورد في العراق وسوريا. وأما الدول الإسلامية حاليا، فكانت الدولتان تقرران في اسم دولتهما بالإسلامية، وهما وجمهورية الإيران الإسلامية، وجمهورية باكستان

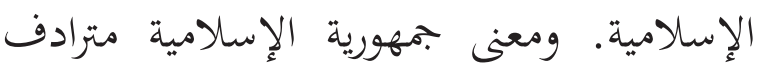
بالدول الإسلامية، كما أن شريعة الإسلامية أيضا هي دستور أساسي لدولة. خلافا لمملكة العربية

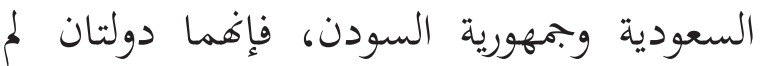
تقررا في اسم دولتهما إسلامية، ولكن الدولتان

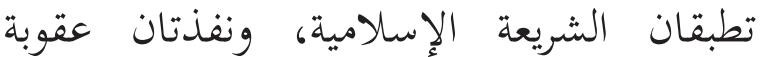
الإعدام لجريمة خطيرة مثل جريمة القاتل، والزاني، وجريمة المخدرات. الخلاصة 
قائمة المراجع (القع

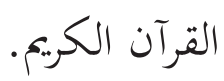
أحكام الإعدام وما نفذ من أحكام في عام الكام

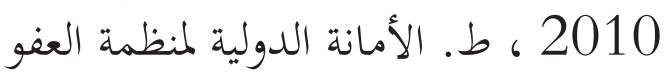
الدولية- لندن- المملكة المتحدة، الأولى سنة المنة pdf 2011

آن دُوزي، رينهارت بيتر آن (المتوفي: 1300هـ)، تكملة المعاجم العربية، نقله إلى آلى العربية وعلق عليه : محمَّد سَليم النعَيمي جمال الحمال

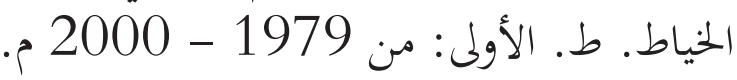

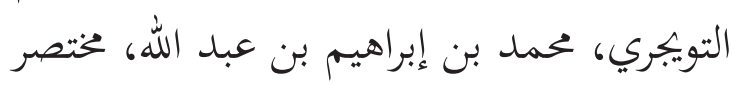

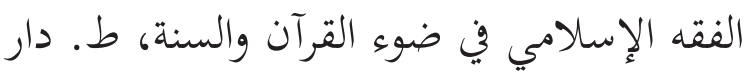
أصداء الجتمع، المملكة العربية السعودية، الحلادية

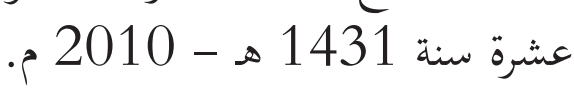
الجعفي البخاري، محمد بن إسماعيل، أبو عبد

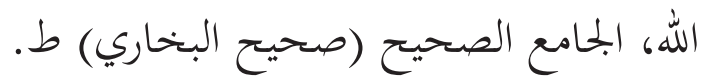
دار طوق النجاة الأولى سنة 1422 هـ تحقيق: محمد زهير بن ناصر الناصر.

الزحيلي، وهبة بن مصطفى، التفسير المنير في نيف

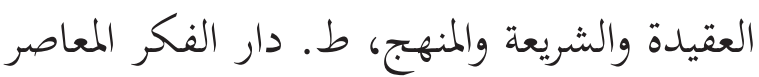

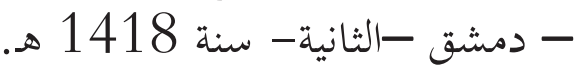
الزحيلي، وهبة بن مصطفى، الفقه الإسلامي وأدله. دار الفكر - دمشق - سوريَّة - الرابعة الإية

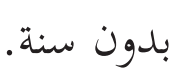

سابق، سيد، فقه السنة، ط. دار الكتاب لئلة العربي، بيروت - لبنان، الثالثة سنة دالثيد 1397 هـ

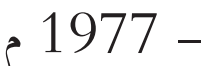

السحيباني، محمد بن ناصر، دفاع عن العقوبات الإسلامية. ط. الجامعة الإسلامية بالمدينة المنورة
العنف والقسوة والوحشية. وتنفيذ عقوبة الإعدم قد تكفل الإسلام على احترام حقوق الإنسان

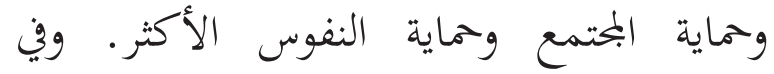
تطبيق الشريعة الإسلامية عاما وعقوبة الإعدام النمام

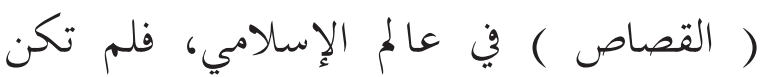

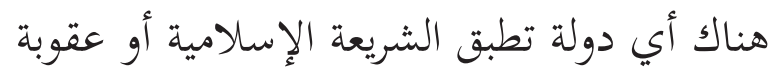
الإعلدام ( القصاص ) كما فعلها رسول الله صلى اللى

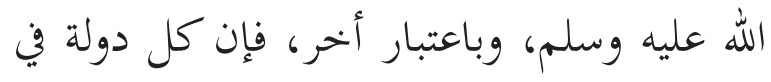
تطبيق عقوبة الإعدام إما بقطع الرأس لجريكة قتل

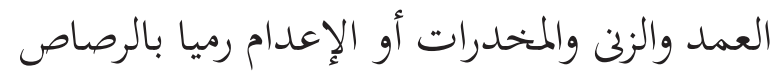

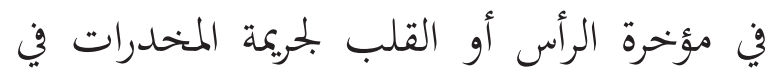

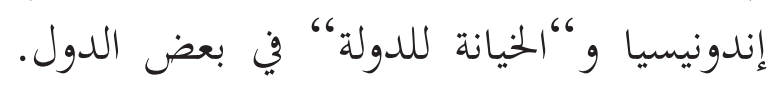
وإن بعض الدول في تطبيق الشريعة الإسلامية مازال في مستوى المكالمات والمحادثات وقليق الثيل منها في مستوى التطبيقات. والتدخل المخاديات الخارجي، خصوصا غير المسلمين، كالتدخل الإقتصادي التخادي، والسياسي والعسكري، يسبب تطبيق الشئل الشريعة

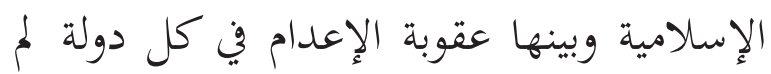

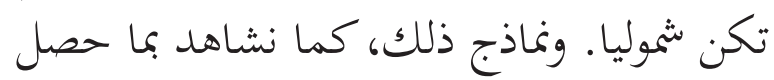
لجمهورية السودان، وجمهورية الإيران الإسلامية، وجمهورية باكستان الإسلامية. لأجل ذلك، كان إقبال الأمة الإسلامية لعقوبة الإنة العادية

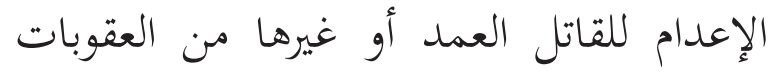

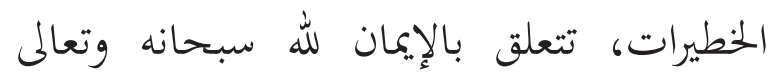

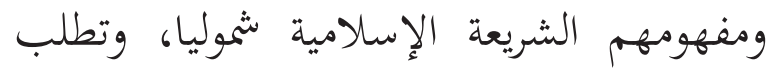

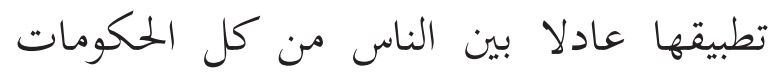
الإسلاميات في الدول المسلم والدول الإسلامية،

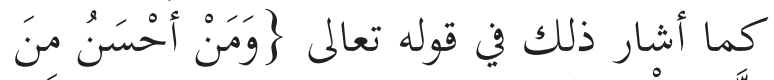

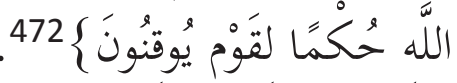

$50 . \overline{~: ~} 50$ 
يسألونك. ط. جـ 1 - 10/ مكتبة دنديس،

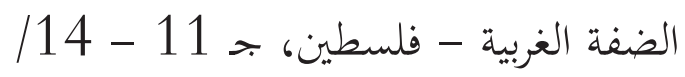
المكتبة العلمية ودار الطيب للطباعة والنشر، الطبة القدس - أبو ديس. الأولى - سنة 1427 - 1430 1430

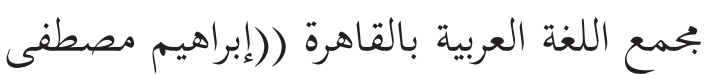

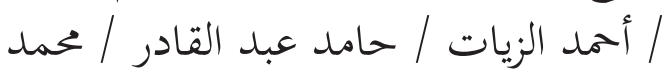

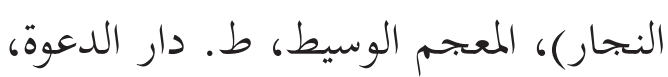
بدون سنة الطباعة.

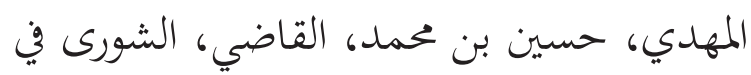

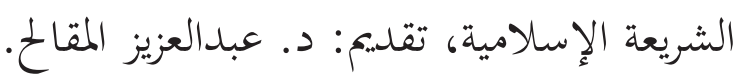
بدون طباعة وسنة. النيسابوري القشيري، مسلم بن الحجاج أبون

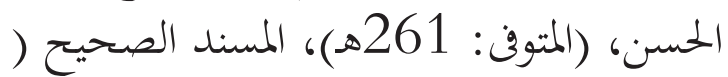

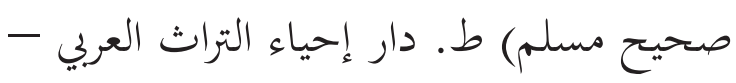
بيروت. تحقيق: محمد فؤاد عبد الباقي. www.amnestyinternational.com www.amnestyinternational.org
- السادسة عشر - العددان الثالث والستون، الرابع والستون رجب - ذو الحجة سنة 1404 هـ الطبري الآملي، محمد بن جرير بن يزيد بن كثير

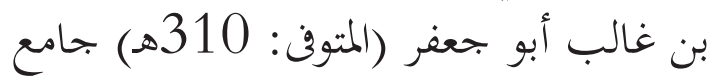
البيان في تأويل أي القرآن. ط. مؤسسة الرسالة

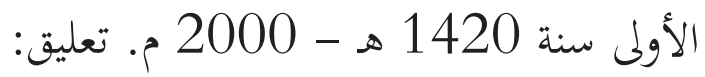

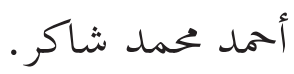
عودة، عبد القادر، التشريع الجنائي الإسلامي لماني

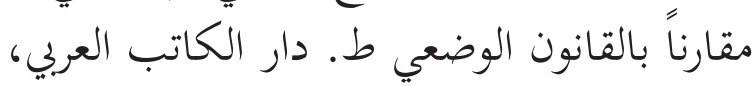
بيروت، بدون سنة. عمر أحمد مختار، معجم الصواب اللغوي دليل

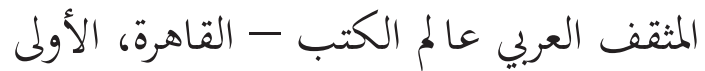
سنة 1429 هـ - 2008 م. عمر، أحمد مختار عبد الحميد، معجم اللغة

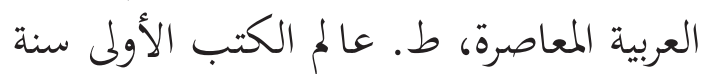

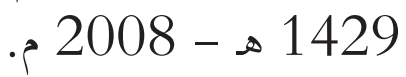
عفانة، حسام الدين بن موسى، فتاوى ملان 